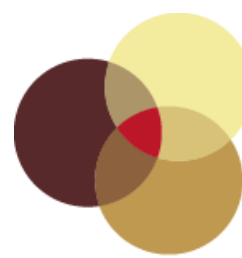

contenmporaneineity

Vol 4, No 1 (2015) ～ISSN 2155-1162 (online)

DOI 10.5195/contemp.2015.157

http://contemporaneity.pitt.edu

\title{
The Round Table 03 圆桌 \\ A Conversation with Xu Bing
}

Madeline Eschenburg and Ellen Larson

\begin{abstract}
The following is an excerpt from a conversation between contemporary Chinese artist Xu Bing, Madeline Eschenburg, and Ellen Larson. Xu Bing curated an exhibition at the Central Academy of Fine Arts titled The Second CAFAM Future Exhibition, Observer-Creator: The Reality Representation of Chinese Young Art, on display through March 2015. Our conversation centered around his thoughts on a new generation of young Chinese artists as well as reflection on his own early career and time in New York. The conversation was conducted in Chinese and has been translated into English.
\end{abstract}

\section{About the Artist}

Xu Bing was born in 1955 in Chongqing. After the Cultural Revolution ended in 1976, he enrolled in the Central Academy of Fine Arts in Beijing, focusing his studies on printmaking. In 1989, he participated in the groundbreaking China/Avant Garde exhibition curated by Gao Minglu. Xu Bing moved to the United States in 1990 and stayed there until his return to China in 2008. Xu Bing is one of the foremost contemporary artists working today, investigating meaning and language, informed by social and cultural conditions. His works aim to "make art serve the people," shaped by both personal and shared histories. Xu Bing currently lives and works in Beijing and New York. 


\section{The Round Table 03 圆桌 January 29, 2015}

Madeline Eschenburg and Ellen Larson
Question: How do you see young artists today?

\author{
访：您现在对今天年轻艺术家有什么看法？
}

Xu Bing: Right now we are working on "The Second CAFAM (Central Academy of Fine Arts Museum) Future Exhibition, Observer-Creator: The Reality Representation of Chinese Young Art," which is really great. But, do you mean how I feel about young artists, or what?

徐冰: 我们正在搞这个未来展第二次。都挺好的。你问我对年轻艺术家的感觉还是怎么样？

Q: Yes, I mean, how do you feel about their notions in terms of the creation of their work?

访: 对, 就是您对他们创作艺术的概念?

XB: I think young people have a lot of conveniences. For example, young people today, their thinking is actually quite open because no matter what, information channels and a large part of culture have been flattened out, or brought to the same level. So the things that they think about and come in contact with are actually in step with one another. Also, because of China's various characteristics, it possesses even more of this kind of information. Even though government control might be a little tight, it can't control young peoples' access to this information. (Young people) can use software to breach China's firewall, so essentially, young people have access to anything they want. This is not as easy for us. Of course, at the same time, they are filled with a kind of government ideology or influence, creating conflict, or what appears to be conflict between things they have access to from the rest of the world. But young artists are actually enriched by these things that exist within China. In other places, young people don't have this sort of information. Therefore, Chinese young people are able to see things within a much wider span. This sort of breadth of thinking is very unusual.

I think Chinese young people are very thoughtful, actually. So, work by young people can be really interesting. Their modes of thinking, which are channeled in terms of the relationship between technology used in society and their peripheral status, is different from when we were young, very different. Also, these young people don't have as many burdens to carry. Another aspect is that they have their own individual personalities. But at the same time, they lack in terms of judgment and independence, and their influence from the West is very profound, really very profound. All of China is deeply influenced by the West. So, the relationship between young people today and the West isn't like the relationship my generation had with the West in the 1980s. At that time, many of us artists were very open. We studied the West. We studied new culture. We studied new thinking. Young people today have become more aware of the value of Chinese culture. They want to represent Eastern thinking or attitudes that are different from the West. But a great portion of young people cannot really do this. So while you're using Eastern materials, your artistic concepts are, in fact, still extremely Western. So, young people today are a really rich phenomenon.

徐冰: 我都是觉得他们都是挺方便的。比如说, 现在年轻人他们确实思维挺开阔的因为不管怎么样这个信息 渠道和这个整个的这种文化被扁平化被拉平了。所以他们想的事情和接触到东西我觉得实际上是同步的。而 且中国这个地方还是由于各种各样的特殊性它真的还是有更多的这种信息。虽然是政府可能管这个有点严, 但是实际上控制不住这些年轻人对这些信息获取的方式，翻墙软件等等。基本他们要的东西都可以去拿到。 这我可能没有那么方便。当然他同时有补充的政府的一种意识形态的一种影响力吧。和这个东西确实很冲突 的, 或者说跟这个全球的东西看起来是很冲突的。但是这个东西确实给这些年轻人补充了。其他的地方年轻 人没有的一种元素。那这些年轻人可以在一个很大的跨度之间想事情。他这种思维的跨度都很怪异。 
这边我是觉得大陆的年轻人还有一个很充分的一个思维的资源其实是。他们思维的方式, 对科技的社会和他 的周边的发生关系的渠道跟我们以前的人不一样, 很不一样。而且你会觉得这些年轻人没有太多负担啦其实 。可是另外的方面就是说他确实有个性, 但是缺少这种正身的这种判断力和这种自主性, 实际上还是受西方 的这种影响很深, 真的很深。因为整体中国就是受西方的影响很深。每一个人其实都是受西方影响非常之深 。所以, 比如说现在这些年轻人其实跟西方的关系, 他们不像我们八十年代的时候。当时我们很多艺术家都 很开放, 学习西方, 学习新的文化, 新的思想。现在年轻人开始意识到中国的文化很有价值。他们想表达东 方的思想或者和西方不同的这种态度。可是呢实际上很深的一部分他又无法 摆脱这个。所以你用的东西是 东方的材料或者怎么样但实际上那个在艺术概念和方法上还是非常西方的。所以年轻人其实（是）很丰富的 现象。

Q: I've read the letter that you wrote to the young artist.

访：我看过你给一个年轻艺术家写的一封信。

XB: This was in the 1990s. I wrote this letter after arriving in New York.

徐冰：这是 90 十年代的时候, 我到纽约之后写（的）这一封信。

Q: Right, so I'd like to ask, from the time you wrote that letter until now, have your thoughts changed at all?

访：对啊。所以我就想问一下, 从当时写这一封信的时候到现在您是否被概念改变?

XB: Actually, the ideas I wrote in the letter haven't really changed much, but my own thoughts have changed. Why? For example, when I first went to the United States, I really hoped to integrate into American culture, to be accepted by American culture. This was my attitude at the time. But now, when I reflect on my attitude during that time, I find it problematic. Now, I think that completely integrating yourself into another system is wrong. If you do so, you lose yourself. If you lose yourself by integrating into another system, you don't exist. Integration makes you become one of them, you know? This is definitely an issue. Only now do I really understand that a place doesn't need what it already has. So where do these things come from? They come from outside of the system. For example, every person who went to New York brought his or her own special qualities, based on family background or personality. So, you have to see whether or not you can use art to share what you have with the art world. But you also have to decide whether or not this place needs what you have to offer. You must give a place what it does not already have itself. But at that time, my works emerged naturally, reflecting the things that I carried with me. When I went to New York, I brought a lot of artworks, but I didn't show them to anyone because I thought they were too old.

徐冰：其实和信上本身没有实质的改变吧。但是观念上其实有变化。比如说什么? 比如说我刚去美国的时候 我们会希望让自己融入美国的文化, 被那个地方接受。当时这是我的态度。但是现在反省那个时候的态度呢 我觉得有问题的。有问题就是说你如果融入那个系统, 就是你这个态度就不对的。融入就把自己就没有了。 你自己都没有了你才融入到那个里面, 你就不存在。融入就是要融进去和他们一样, 是吧? 一定有问题。那 我现在我才能够认识到, 那个地方它不需要一个和他们一样的东西。那这里面有的东西从哪儿来的? 一定 是从这个系统外面来的。比如说每个人到纽约去, 实际上每个人都带自己特殊的, 这种文化的背景或者特殊 的性格的东西。但是就看你能不能用艺术把你的这一部分特殊性的东西给带入艺术界, 但是还要看这个东西 是不是这个地方需要的? 你必须给那个地方本身就没有的。但是当时我一个人在艺术的创作上它就是自然而 然地就把你身上携带的东西给反映出来。我去纽约的时候带来了很多艺术的作品, 但是我当时没拿出来给 别人看因为我觉得太旧了。 


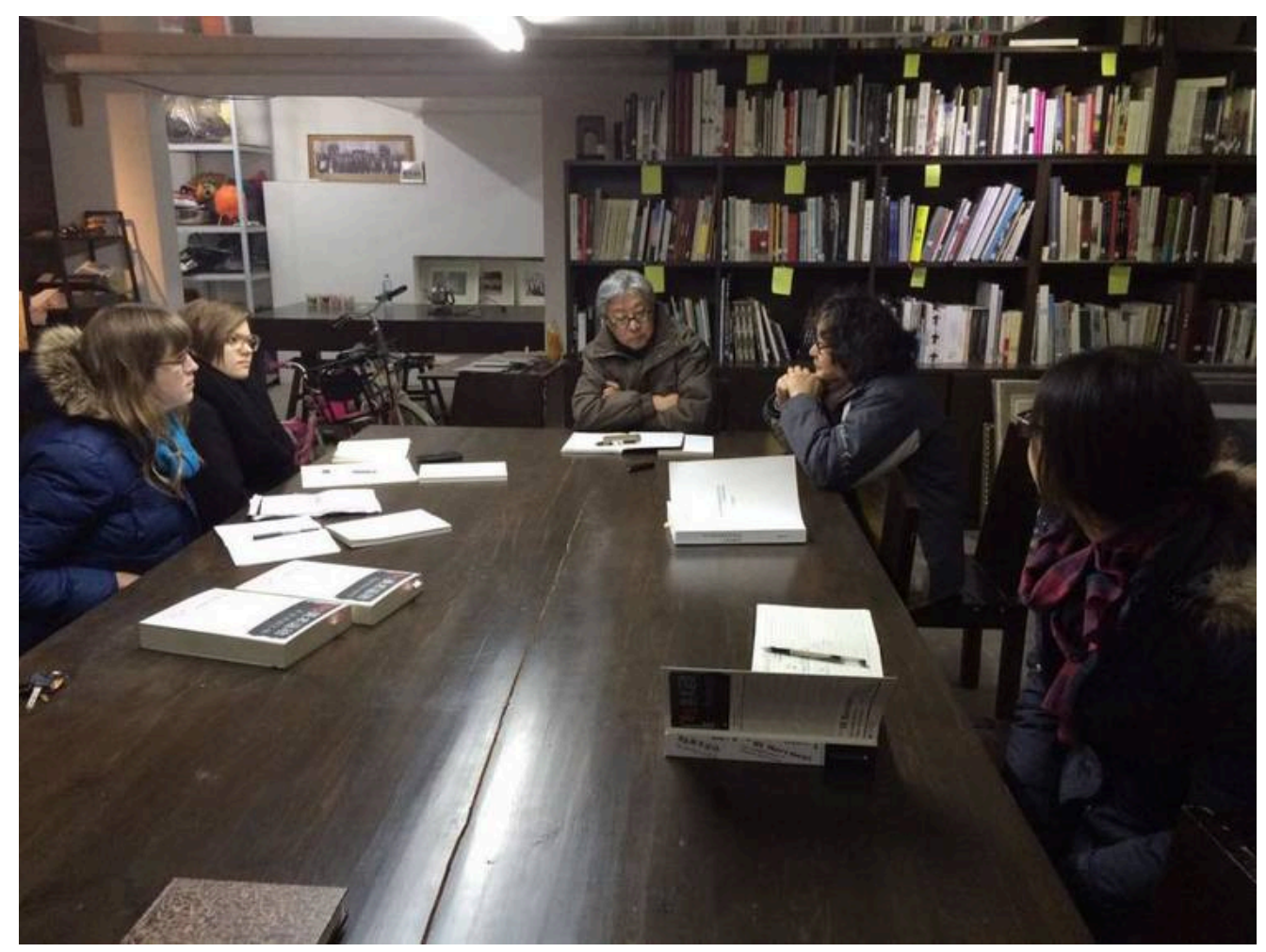

From Left to Right: Madeline Eschenburg, Ellen Larson, Gao Minglu, Xu Bing, and Kuang Liping.

Q: What period were these works from?

访:您是说的那个时代的作品?

XB: They were prints that I made when I was at the Central Academy. These works were exemplary of Chinese socialism. But at that time, I didn't show them to people because I wanted them to think I was a contemporary artist, an innately contemporary artist. But in fact, after you become a good artist and people start to pay attention to your work, they start to become interested in your own history. (They asked) why I made this kind of work. So I showed them these prints so they could see my history. Really, these (older works) helped me. For one, at the time, they represented socialist works. Another aspect is that your family or background was carried through with this Chinese cultural tradition. Both of these things were of help to me. In other words, even though at that time I really wanted my work to be seen as international or contemporary, in fact, the things that I carried were translated into my work. Maybe because I am really sincere, I am able to translate the most real parts of me into my work. Even though I thought I should get rid of all these old things, these things all helped me bring new things into my art, or things that did not exist before. For example, my past work and my current work are not any different conceptually, but at that time, it was unconscious or passive.

徐冰: 就是过去的做的很多版画, 就是在美术学院。就是特别中国的社会主义痕迹的作品。但是我当时没拿 让别人看看因为我想让人觉得我是当代艺术家, 天生的当代艺术家。但实际上你后来做得好大家关注你的作 品最后就跟你的历史感兴趣。（他们问）我为什么做这样的作品。所以我也拿给别人看这样的历史。实际上 这些东西都帮助我了。它一方面是当时那样的社会主义创作的那种模式, 另外一方面你的家庭或者你的背景 带这个中国文化传统的这种东西。那这两个东西其实都帮助我。就是说, 我虽然当时很想让自己的作品非常 国际化或者当代化可是实际上你自己带的东西它就是要反映在你的作品里。也许我这人对艺术挺真诚的, 所 以我的东西都能够反映我的真实的部分。虽然我认识到我要取消我过去的东西但是实际上过去的东西同时帮 
助我, 反倒帮助了我给艺术中带去新的东西, 或者过去没有的东西。那现在就是比起那时候, 由于这么长时 间的实践你就有意识和清除这个东西。比如说, 我过去的时候我的艺术和现在的艺术没有什么概念上的不同 , 可是当时是无意识或者被动的。

Q: Have your thoughts on the relationship between art and society changed in any way?

访：然后您对艺术与社会的关系是否被改变?

XB: At that time, our understanding of the relationship between art and society was formed by our Chinese education. This was the concept that art originated from life. It was something that Chairman Mao discussed during his Yan'an talks. Actually, this language was really political, yet really simple. Our understanding of the relationship between art and society came from this. But, this concept was later simplified, or stylized. For example, at that time, when we were in school "plunging into the thick of life" was emphasized. What does this mean? At that time, it meant going to the countryside, to the border regions, factories, etc. By going to these kinds of places, we could plunge into the thick of life, living together with our fellow countrymen. We lived together, painted, things like that, but I later discovered that these things and what was really the core of life during that time had no relationship to one another. So now, I myself think that art, without a doubt, comes from our life and experiences. But the problem is that the words we use are said without feeling, but actually, their truths still remain the truth. For example, with my own experiences, I think that you must not separate yourself from the period in which you live if you want to become an excellent artist. For example, for Chinese artists, you could say that this place has a lot of ignorance, control, or is extremely politicized. But of course, it's really a kind of special energy, continuously transmitted to artists. For example, I have found that China produces an incredible amount of this kind of energy. From 1949 to the Cultural Revolution, then after the Cultural Revolution to the time we left China, every period in history actually produced huge amounts of energy. But energy is sometimes used in the wrong way. After reform and the opening up of China, I think this energy was honed in the right ways, allowing China to develop so rapidly. Regardless of what kind of system, this place has developed at unprecedented levels. I have become aware that this is all the result of China's own capabilities, something that would not be possible in other places. So an artist is like this. He takes the special energy from a place and transforms it into his artworks. It is only when you understand this that you can become a rather outstanding artist. Sometimes when I will go to Biennales to look at work, I see a lot of work that is actually kind of boring. So then why, after creating work in the United States or around the world and then returning to China, do I think these tastes haven't changed? Before, artistic methods and tastes were all discussed. But at that time, a lot of friends and curators were extremely interested in discussing these things. Of course they held the threads to this work, but for me, these things weren't enough. My acquaintance with the customs here in China has strengthened my pursuit of insightful understanding of the relationship between art and society. I think that this is greater here than in other places, for example, New York. I think that if I stayed in New York, my thinking wouldn't be as strong as it is today. But, with my work Phoenix, I think that if I didn't spend time living in New York, I wouldn't have made this kind of work. This is an example of the relationship between artist and the period in which he lives and works. I returned to China to serve as the Vice President of CAFA for seven years. A lot of people say that during these seven years, I wasted a lot of time, but I think that (this experience) really strengthened my own thinking. My work is different because I now understand this country. When you work within the system, you know what this country is really like; what things propel it forward. In terms of time, each period has its own turning point. People have their own turning points. In terms of my own personal turning point, I think each brings its own aggregation and blossoming of new energy.

徐冰：当时呢其实艺术和社会的关系其实最可信的来自于我们在中国接受教育的, 一个艺术源于生活的概念 。其实就是毛泽东的讲话, 延安会议的概念。其实这句话说得很政治, 很简单。那我们这个对艺术和社会理 解的关系其实源自于这个东西。可是这个东西呢又被后来的艺术界给它简单化或样式化。比如说我们那个时 候上学的时候或者学习特别强调深入生活深入生活, 什么叫深入生活? 当时深入生活就是去农村, 去边远的 , 去工厂, 这些地方去深入生活和老乡住在一块儿。生活在一块儿画画什么的, 但是我后来发现这个东西和 
当时的中国的真正的这个时代的核心都没关系。那个东西其实是一种和这个现实生活核心的命脉是没关系的 。它是一种田园采风式的方式。就是像现在你看中央政府又提倡要深入生活, 到什么边疆去, 去农村去。但 是现在这个东西是不是生活的? 时代的核心 ? 它可能不是。你知道我的意思吧? 所以现在我自己对艺术, 我 是觉得毫无疑问艺术源自于生活那确实是这样的。但是问题是话都是被说的没什么感觉, 可是实际上它的道 理还是这个道理, 比如说我自己的经验, 我就感觉你必须要跟这个时代发生很紧密的关系你才能成为一个很 优秀艺术家。比如说中国艺术家, 在中国这个地方你要说它是愚昧或者控制得很多, 非常政治化。当然它有 它特殊的一种能量, 不断地给艺术家做补充。比如说我发现中国这个地方其实产生巨大能量的一个地方。你 从这个 49 年以后到文革, 到文革以后, 到后来我们出国, 这个每一个阶段其实都是有巨大的能量。只是能量 有时候用得不对。但是改革开放以后这能量我觉得用对地儿了, 所以中国能够发展那么快。你不管这个制度 怎么样, 可是这个地方它就是发展的, 而且实际上是发展得最快的, 前所未有的。我只是意识到不管怎么样 这都是在中国这个地方出现的能量。这个能量可是别的地方不容易有的东西。那作为艺术家呢, 他就是这个 。怎么样懂的, 把这个地方特殊能量的能量转换到艺术的创作上。你懂这个东西你才能成为一个比较优秀的 艺术家。比如说我有的时候会去双年展看作品, 我有时候会觉得有很多作品其实有点无聊。那我为什么会觉 得比如说二十年前, 十五年前, 十年前在美国或者在世界各地参与创作, 现在后来回去了以后感觉这个趣味 没有变化。当代艺术的手段和趣味还是被讨论。但是当时有很多朋友策展人还是特别兴趣在讨论这些东西。 当然它有一个学术的一个线索, 可是对我来说我就感觉这些东西对我不够。我在中国这个地方接的地气和我 的艺术和社会之间的关系的这种思维的密度。我觉得比在其他的地方的艺术家或者至少比我在纽约, 如果我 现在仍然在纽约我想可能不会像我现在的这种思维的这种力度。比如说我作那个《大风》那个作品, 我觉得 如果在纽约生活不会有这样的作品。那这就是艺术家和时代的关系。所以我个人说我回到美院做副院长, 但 是现在我不做, 是吧, 但是我做的七年, 这七年大家会说浪费很多时间, 但是对我来说真的我的思维力度了 , 所以我的工作是不一样, 因为我了解这个国家。你在这个系统中里知道这个国家是怎么样的, 是什么东西 在推动这个国家走的。对时代来说, 时代有时代的转折, 个人有个人的转折。那我的个人的转折, 我是觉得 每一个转折都会聚集和晕染新的能量。 
(cc) $\mathrm{BY}$

New articles in this journal are licensed under a Creative Commons Attribution 4.0 United States License.

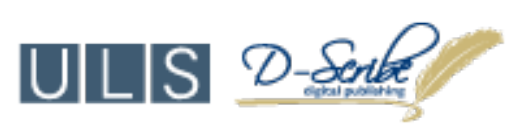

This journal is operated by the University Library System of the University of Pittsburgh as part of its D-Scribe Digital Publishing Program, and is co-sponsored by the University of Pittsburgh Press. 